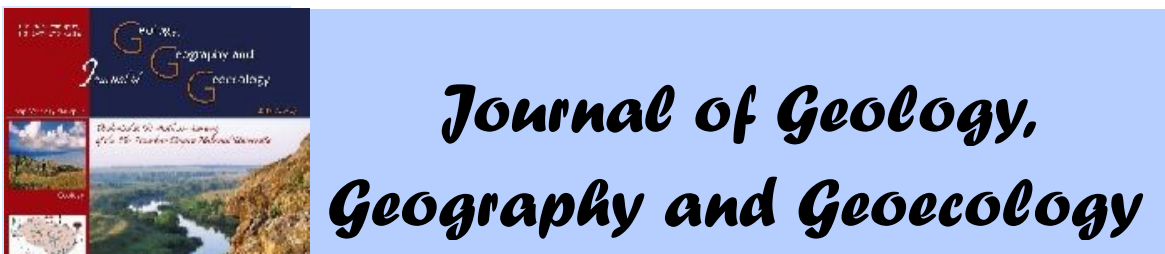

Journal home page: geology-dnu-dp.ua
ISSN 2617-2909 (print)

ISSN 2617-2119 (online)

Journ.Geol.Geograph. Geoecology, 27(2), 222-231 doi: $10.15421 / 111847$

D.V. Kasiyanchuk, E.D. Kuzmenko,

M.M. Tymkiv, A.V. Vitiuk

Journ.Geol.Geograph.Geoecology, 27(2), 222-231

\title{
Geo-information modelling of the insolation level within Ivano-Frankivsk region
}

\author{
D.V. Kasiyanchuk, E.D. Kuzmenko, M.M. Tymkiv, A.V. Vitiuk
}

Ivano-Frankivsk National Technical University of Oil and Gas, e-mail: dima_kasiyanchuk@ukr.net

Received 02.05.2018;

Received in revised form 12.07.2018;

Accepted 30.07.2018

Abstract.Useof alternative energy sources is one of the promising directions in economic and environmental development of any territory. The purpose of this article is to conduct geo-information analysis of the insolation level within Ivano-Frankivsk region located in the western part of Ukraine. When considering any research territory, it is worth conducting a factorial analysis, which gives the possibility to characterize any advantages and disadvantages of the use of alternative energy. Justification of approaches to the study of territories where alternative energy sources are located or generated is needed to create a unified system for assessment of the potential of the renewable energy sources. According to data of the European Space Agency, the insolation level on the research territory varies from 1175 to $1425 \mathrm{~kW} / \mathrm{hour*}$ sq. $\mathrm{m} /$ per day. The method of our research involves the statistical analysis of the insolation level and the factor approach to determining the existing level of insolation Insolation values, meteorological and geomorphological factor characteristics are used to substantiate the new methodology for calculating the existing insolation level. According to the statistical analysis and geo-information analysis, this reasonably permits us to structure months by the level of insolation as well as to calculate the insolation level at a specific point for a certain time of year. Taking into account the angle of inclination above the horizon - the Sun's declination, the slope exposure the Sun's azimuth gives us the possibility to reduce the value of the relief point with its selected factor characteristics and the insolation value to the single coefficients, which permits us to clarify the information as to the insolation level of the selected region. Finally, this is resulted in creation of a map with the isolation levels for Ivano-Frankivsk region taking into account the factor characteristics. The map represents the changing of the insolation level for seven grouped months. It should be noted that insolation level is uneven and it is characterized by the widest gradation within the territories with complex relief. In that event, the optimal angle of solar photovoltaic module inclination equals $49^{\circ}$ within Ivano-Frankivsk region. Such structuring clearly reflects the dynamics of changes in the insolation level for an individually selected zone. The scientific novelty of the obtained results is assessment of distribution of the solar energy potential required for further selection of areas to design and locate the solar power stations. The practical significance lies in obtaining the digital cartographic materials which allow assessment of the insolation value at a specific point in the studied region. Structuring of the insolation maps gives the possibility for further development of a unified insolation assessment scheme that is convenient for any user.

Key words: solar insolation, geo-information analyses, potential, renewable energy sources

\section{еоінформ ційне моделюв ння рівня інсоляції території в но- р нківської обл сті}

\author{
• . сіянчук, . . узьменко, . . имків, . . ітюк \\ в но- $\quad$ нківський н ціон льний технічний університет н фти і г зу, м. в но- $p$ нківськ, кр їн , \\ e-mail:dima_kasiyanchuk@ukr.net
}

нот ція. икорист ння льтерн тивних джерел енергії є одним із н йперспективнішим н прямком економіко-екологічного розвитку територій. етою публік ції є геоінформ ційний н ліз рівня інсоляції території в но- р нківської обл сті, як розт шов н у з хідній ч стині кр їни. ри розгляді будь-якої території досліджень, в рто викон ти ф кторний н ліз, що дозволить ох р ктеризув ти усі перев ги н недоліки використ ння льтерн тивної енергетики. бгрунтув ння підходів до вивчення територій розміщення т видобутку льтерн тивних джерел енергії виклик но необхідністю створення єдиної системи проведення оцінки потенці лу відновлюв льних джерел енергії. івень інсоляції н території дослідження змінюється від1175 до 1425 к т/год*Кв.м в день згідно з д ними вропейського космічного генств . етодик роботи поляг $є$ у ст тистичному н лізі рівня інсоляції т у ф кторному підході до визн чення приведеного рівня інсоляції. н чення інсоляції, метеорологічні т геоморфологічні ф кторні х р ктеристики використ ні для обгрунтув ння нової методики розр хунку 
приведеного рівня інсоляції. е дозволило н основі ст тистичного т геоінформ ційного н лізу обгрунтов но підійти до структурув ння місяців з рівнем інсоляції т розр хунку рівня інсоляції в конкретній точці для певного періоду року. $\quad$ p хув ння кут н хилу схилу - схилення онця, експозиції схилу - зимут онця дозволило привести зн чення точки рельєфу з його вибр ними ф кторними х $\mathrm{p}$ ктеристик ми т інсоляційним зн ченням до єдиних коефіцієнтів, які дозволили уточнити інформ цію щодо рівня інсоляції обр ного регіону. інцевим результ том є побудов н к рт рівнів інсоляції для території в но- р нківської обл сті з ур хув нням ф кторних х р ктеристик. рт репрезентує зміну рівня інсоляції для семи згрупов них місяців. еобхідно відмітити, що рівень інсоляції є нерівномірним, і н йбільшою гр д цією він х р ктеризується н територіях зі скл дним рельєфом. ри цьому оптим льний кут н хилу сонячного фотомодуля для території в но- $\mathrm{p}$ нківської обл сті $€ 49^{\circ}$. ке структурув ння н очно відобр ж є дин міку зміни рівня інсоляції для окремо вибр ної зони. у уковою новизною одерж них результ тів є оцінк розподілу потенці лу використ ння сонячної енергії, необхідної для под льшого вибору ділянок проектув ння т розміщення сонячних електрост нцій. $р$ ктичн зн чимість поляг є в отрим нні цифрових к ртогр фічних м тері л х, які дозволяють оцінити зн чення інсоляції в певній точці досліджув ного регіону. труктурув ння к рт інсоляції д є змогу в под льшому розробити уніфіков ну схему оцінки інсоляції, зручну для будь-якого користув ч .

лючові слов : сонячн інсоляція, геоінформ ційний н ліз, потенці л, відновлюв льні джерел енергї̈

Problem definition. The growth of multi-year world temperatures, which is mainly conditioned by increase in the carbon monoxide content, promotes interest in planning and sustainable development of economic activity in the country. The use of solarcell panels is one of the effective methods of electric power and heat production. Unlike the traditional methods (such as burning of hydrocarbons, using atomic energy, etc.), they are not so widely used but arouse interest because of their environmental friendliness and renewability. The introduction and ecological justification of the solar-cell panels require the knowledge of the reduced insolation level $\left({ }_{n p}\right)$ in regions as well as the factors that may influence the functioning of such energy systems. The use of geo-information systems (GIS) will offer the possibility to unify the process of selecting territories and assessing potential of the renewable energy sources (RES).

Analysis of recent researches and publications. Working out the energy-efficient programs, which are co-financed by state and international funds, allows measures to be planned for the development of alternative energy sources. These programs in their regulatory and technical aspect are governed by the State Agency on Energy Efficiency and Energy Saving of Ukraine, in accordance with the 'National Strategy 2035'(Sukhodolya, 2014).

The need to develop alternative sources as a resource base has encouraged further development in the scientific work by (Ellabbanab, Abu-Rubb, Blaabjergc, 2014). The authors have analyzed the technological basis of extraction and prospects of using alternative energy resources in future.

The problem connected with the influence of direct sunlight, as a factor of the insolation duration, and the form of buildings and structures was considered in the scientific work by Kazakov G.V. (Kazakov, 2013), in which the author has specified the morphological role of the environment.
The scientific work by (Dotsenko, 2016) shows the connection between the insolation and consumption of energy in accordance with the geographic location of the solar-cell panels, weather conditions, and seasons.

British scientists have made a significant contribution to developing the issue. They are considering in detail the solar insolation level on cloudless and cloudy days.

Their examination results show that the insolation level varies with respect to the latitude, day length, location of absorption plane, as well as extent of cloud cover (Twidell, Weir, 2015).

The amount of solar energy amount which falls on the Ukrainian territory has been analyzed according to geographical location, namely according to latitudes, in the scientific work by (Gelichy, 2015). The author has obtained empirical functional relations to calculate the solar energy reaching the Earth's surface.

There is a need for rational use of the land resources, especially of those areas which are not suitable for active economic activity but which may be used for generating alternative energy. This is especially important when there is a problem of significant negative influence over the environment (Tiapkin, Pihulevskyi, Dovbnich 2017).

Highlighting of previously unsolved parts of the general problem. Analysis of the renewable energy sources within Ivano-Frankivsk region by means of the geo-information system (Tymkiv, Kasiyanchuk, 2017) is one of the promising directions in research due to the availability of significant energy renewable potential, which is not yet exploited.

An organized system for solar potential assessment is created by means of developing a structure for selecting and analyzing factors that determine the insolation level.

Determination of a solar power plants' (SPP) potential does not depend on the solar insolation only but it is also related to a number of values of 
the Earth's daily rotation around the Sun. Therefore, we need to consider the factors which permit us to substantiate the new approaches to the geo-information analyses of the insolation level. Calculation of the insolation level which is conducted without regard to even one of the groups of factors does not make it possible to assess its value with a high degree of reliability, because the basic factor, the morphological characteristic of the territory, is not taken into consideration. Construction of the large energetic complexes of renewable energy is impossible without taking into consideration the tectonic and landscape factors, which in their dynamics, may significantly restrict the functioning of such solar-cell panels.

Formulating of the aim of the article (task assignment). In order to achieve the aim, we have to analyze the progress in the field of REW and the experience of using GIS for its assessment. Determination of the optimal angle of solar-cell panels permits us to develop a high-quality project for stationary energetic objects. At the same time, there is a need to draw up the morphological maps of the region, a map of the solar insolation, as well as to calculate the reduced insolation level in the chosen territory at the initial stage during development of a system for assessing the potential and expediency of using the renewable energy sources in Ivano-Frankivsk region.
Description of the methodology (the structure and sequence) for the research. The choice of territory for rational use of the natural (renewable) resources depends to the large extent on the selected type of RES. Each RES has its own spatial characteristic with the highest potential (availability of quickly renewable biological resources and areas where they are cultivated; proximity to geothermal horizons; territories that are not used for economic activity for construction of SPP, etc.).

Database creation and selection of factors (Kasiyanchuk, Chepurna, Chepurnyi, Hurtska, 2015; Kasiyanchuk, Kuzmenko, Chepurna, Chepurnyi, 2016; Suri, Cebecauer, Huld, Dunlop, 2008), structuring and analysing the data which determine one or another RES provide the possibility to conduct analyses on the example of any territory.

The insolation level depends to the large extent on geographic reference. The results of ERS permit the assessment of the full (maximum) value of the insolation according to the latitude and longitude of the selected region. Fig.1 presents the digital map of the insolation level within the territory selected for our analyses, pursuant to data by the European Space Agency (NASA, 2018). An uneven distribution of the solar energy with conditional division into seven insolation zones is shown on the map.

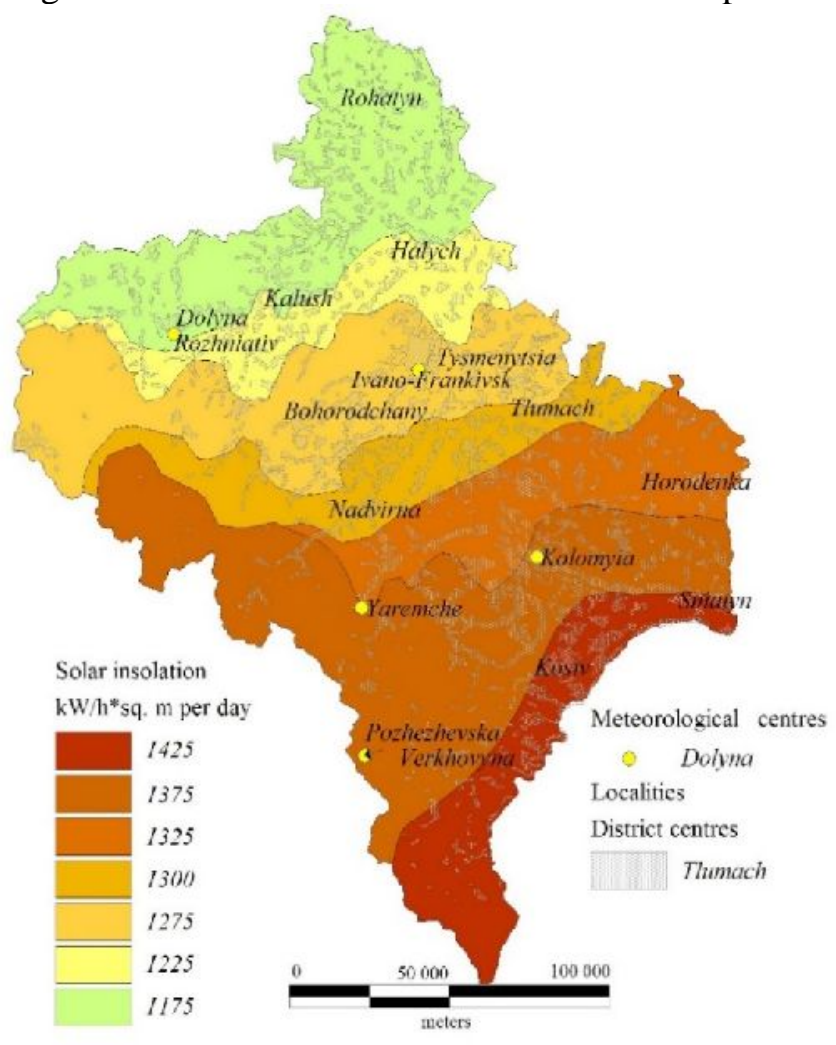

Fig. 1. Map of solar insolation of Ivano-Frankivsk region 
There is a need to create a unified system for assessment of RES potential (Fig.2). It is advisable to analyze the stages of assessment of RES potential, based on the proposed scheme.

At the first stage, there is a choice of certain renewable energy sources, for which we should calculate a potential within one or another territory.

The second stage involves a well-grounded analysis of the territory where the renewal energy sources are planned to be put into production.
The third stage envisages the following: creation of the database, which includes digital topographic maps, vegetation maps, maps of tectonic disturbances, maps of meteorological conditions, etc.; insolation maps with division into zones; calculation of the factor characteristics (measures of factor determination); statistical analysis of changes in insolation level depending on selected factors.

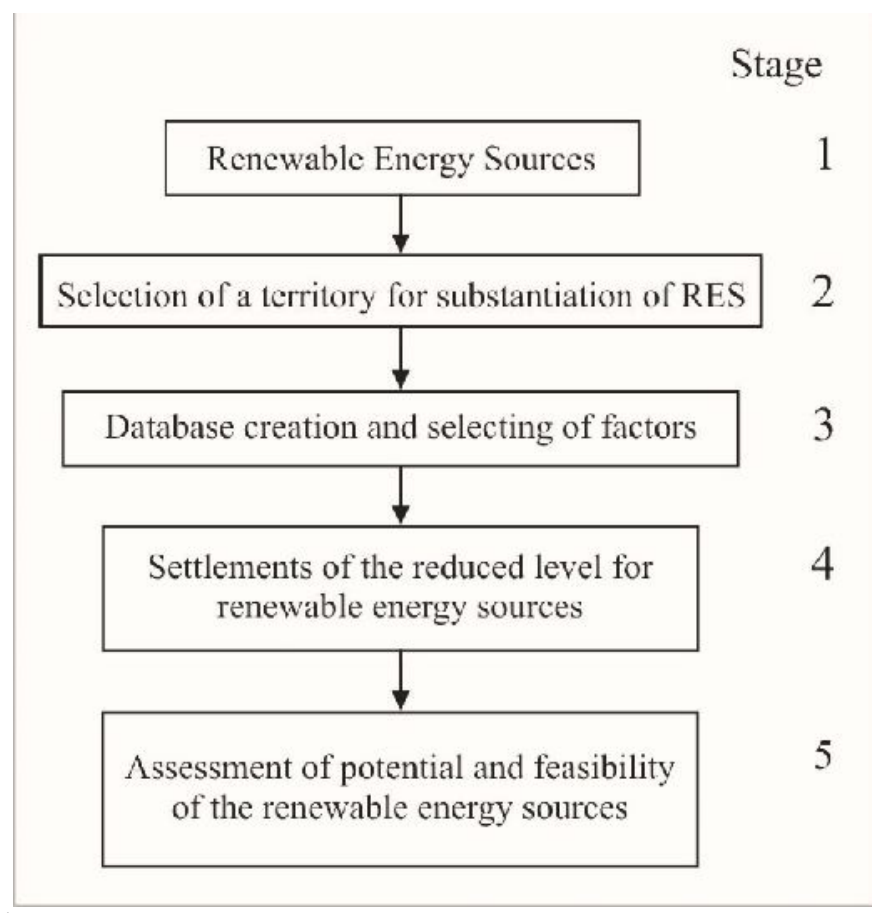

Fig. 2. Scheme of RES potential assessment

At the fourth stage, the settlements of reduced level of the renewable energy sources give us the possibility to perform calculation by using the methods of geo-information analysis and to assess the territory that may be potentially used for the energy generation.

On the basis of the above-mentioned items, the fifth stage justifies the possibilities and risks to construction of the energy facilities in terms of their special location and time dynamics.

One of the most important elements in RES analysis shall be a choice of factors influencing potential calculation.

It is necessary to take into consideration meteorological, geomorphological, tectonic, hydrogeological and landscape factors (Table 1) when constructing SPP.

At the same time, analysing Ivano-Frankivsk region according to the insolation zones (Fig. 1) includes the change of azimuth and an angle of the Sun's inclination during the day at any point of the zone, daily movement of the Sun, and geomorphological characteristics of the selected point. This is required for calculation of the insolation level.

Let us determine the insolation in real cloud conditions for the latitude of Ivano-Frankivsk region. According to NASA [14], the average annual insolation at the latitude of $\varphi=48^{\circ}$ equals to $1076.7 \mathrm{kWh} / \mathrm{m}^{2}$. We may determine the cloud coefficient (Table 2), which considers the morphological and meteorological factors by the ratio of insolation in real cloud conditions to insolation on a cloudless sky.

The selected point within the insolation zone shall be determined by absolute height, angle of inclination, exposure and the average insolation level within a day (where the effectiveness of solarcell panels is above zero) and the coefficient that substantiates grouping in months according to the solar insolation ( 7 groups in total) (Table 3 ). 
Table 1. Factors that influence construction of SPP

\begin{tabular}{|c|c|c|}
\hline $\begin{array}{l}\text { Group of driving } \\
\text { forces }\end{array}$ & Factors & Factor characteristics \\
\hline Geological & $\begin{array}{c}\text { Availability of areas with } \\
\text { breach of the geological } \\
\text { medium } \\
\text { (lithofacial rocks) }\end{array}$ & $\begin{array}{c}\text { Distance to areas with breach } \\
\text { of the geological medium } \\
\text { (faults, karst, mudflows, } \\
\text { open-cut mining) }\end{array}$ \\
\hline Hydrogeological & $\begin{array}{l}\text { Availability of water sup- } \\
\text { ply and drainage zones }\end{array}$ & Skin-factor \\
\hline \multirow{3}{*}{ Meteorological } & Precipitations & Intensity and frequency \\
\hline & Temperature & Season temperature change \\
\hline & Atmosphere pressure & $\begin{array}{l}\text { Cloud coefficient, changing } \\
\text { of atmosphere pressure (air } \\
\text { humidity) }\end{array}$ \\
\hline Tectonic & Tectonic disturbances & Distance to tectonic fault \\
\hline Landscape & Vegetation & Forested area \\
\hline \multirow{3}{*}{ Geomorphological } & Height & $\begin{array}{c}\text { Absolute estimate over the } \\
\text { sea level }\end{array}$ \\
\hline & Slope inclination & $\begin{array}{l}\text { Angle of inclination of day- } \\
\text { light surface }\end{array}$ \\
\hline & Direction of slope & Slope exposition \\
\hline
\end{tabular}

Table 2. Insolation in cloud and cloudless conditions, $\mathrm{kW} / \mathrm{m}^{2}$, and cloud coefficient

\begin{tabular}{|c|c|c|c|}
\hline Month & $\begin{array}{c}\text { Insolation during cloudless } \\
\text { sky per month }\end{array}$ & $\begin{array}{c}\text { Insolation during cloudy sky } \\
\text { per month }\end{array}$ & Cloud coefficient \\
\hline January & 59.21 & 36.89 & 0.62 \\
\hline February & 86.24 & 54.04 & 0.62 \\
\hline March & 146.32 & 88.04 & 0.60 \\
\hline April & 188.4 & 110.4 & 0.58 \\
\hline May & 225.06 & 140.74 & 0.62 \\
\hline June & 231 & 142.5 & 0.61 \\
\hline July & 221.96 & 147.56 & 0.66 \\
\hline August & 196.23 & 136.4 & 0.69 \\
\hline September & 154.8 & 91.8 & 0.59 \\
\hline October & 104.16 & 62 & 0.59 \\
\hline November & 64.2 & 37.2 & 0.57 \\
\hline December & 48.98 & 29.14 & 0.59 \\
\hline Amount per year & 1726.56 & 1070.71 & - \\
\hline
\end{tabular}

The value of insolation is uneven throughout the year. Regression analysis, Spearmen's rankcorrelation, makes it possible to see that some months are connected with each other and they are may be divided into three following groups: 1) January, February, March; 2) April, May, June; 3) July, August. There are also months that are not correlated with other months, such as September,
October, November, and December.

The proximity of values is explained by the fact that the insolation level of the territory falls within a narrow range. Obviously, Spearmen's rank-correlation coefficients will show the change of insolation as a homogenous monotonic relation between recorded factors. That may be grouped by months. Significant values equal to 1 or -1 . 
Table 3. Spearmen's rank-correlation analyses

\begin{tabular}{|c|c|c|c|c|c|c|c|c|c|c|c|c|}
\hline $\begin{array}{l}\text { F } \\
\stackrel{+}{0} \\
\sum^{\circ}\end{array}$ & 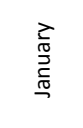 & 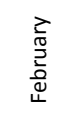 & $\begin{array}{l}\frac{5}{5} \\
\stackrel{5}{\pi} \\
\sum\end{array}$ & $\overline{\bar{z}}$ & $\sum^{\frac{\pi}{2}}$ & $\stackrel{巳}{\Xi}$ & 引 & $\begin{array}{l}\text { 莏 } \\
\frac{a}{z}\end{array}$ & 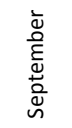 & 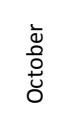 & 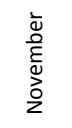 & 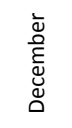 \\
\hline & 1 & II & III & IV & v & VI & VII & VIII & IX & $x$ & $\mathrm{XI}$ & XII \\
\hline 1 & 1 & 1 & 1 & 0,949 & 0,949 & 0,949 & 0,949 & 0,949 & 0,953 & 0,965 & 0,948 & 0,911 \\
\hline II & 1 & 1 & 1 & 0,949 & 0,949 & 0,949 & 0,949 & 0,949 & 0,953 & 0,965 & 0,948 & 0,911 \\
\hline III & 1 & 1 & 1 & 0,949 & 0,949 & 0,949 & 0,949 & 0,949 & 0,953 & 0,965 & 0,948 & 0,911 \\
\hline IV & 0,949 & 0,949 & 0,949 & 1 & 1 & 1 & 0,983 & 0,983 & 0,995 & 0,983 & 0,966 & 0,957 \\
\hline $\mathrm{v}$ & 0,949 & 0,949 & 0,949 & 1 & 1 & 1 & 0,983 & 0,983 & 0,995 & 0,983 & 0,966 & 0,957 \\
\hline $\mathrm{VI}$ & 0,949 & 0,949 & 0,949 & 1 & 1 & 1 & 0,983 & 0,983 & 0,995 & 0,983 & 0,966 & 0,957 \\
\hline VII & 0,949 & 0,949 & 0,949 & 0,983 & 0,983 & 0,983 & 1 & 1 & 0,970 & 0,983 & 0,966 & 0,957 \\
\hline VIII & 0,949 & 0,949 & 0,949 & 0,983 & 0,983 & 0,983 & 1 & 1 & 0,970 & 0,983 & 0,966 & 0,957 \\
\hline IX & 0,953 & 0,953 & 0,953 & 0,995 & 0,995 & 0,995 & 0,970 & 0,970 & 1 & 0,987 & 0,970 & 0,961 \\
\hline$x$ & 0,965 & 0,965 & 0,965 & 0,983 & 0,983 & 0,983 & 0,983 & 0,983 & 0,987 & 1 & 0,982 & 0,973 \\
\hline $\mathrm{XI}$ & 0,948 & 0,948 & 0,948 & 0,966 & 0,966 & 0,966 & 0,966 & 0,966 & 0,970 & 0,982 & 1 & 0,956 \\
\hline XII & 0,911 & 0,911 & 0,911 & 0,957 & 0,957 & 0,957 & 0,957 & 0,957 & 0,961 & 0,973 & 0,956 & 1 \\
\hline
\end{tabular}

Spearman's correlation matrix includes meteorological and morphological factors. Substantiation of conditional division of the year according to the insolation level for IvanoFrankivsk region is conducted according to the fact that the insolation provision of the territory cannot be the same because the factors of precipitation, atmosphere pressure, height, etc. in their totality have a significant influence on the level of the potentially obtained solar energy.

In order to calculate the reduced insolation level $\left({ }_{n p}\right)$, it is important to take into account the main condition for effective work of SPP, which is the number of cloudy and cloudless days, in the form of the relevant cloud coefficient for the studied territory. In turn, such grouping in months permits us to assert that the annual distribution of the solar energy is uneven with respect to the results of statistical analyses.

Presentation of the main material and obtained scientific results. Description of how to select a

The Sun

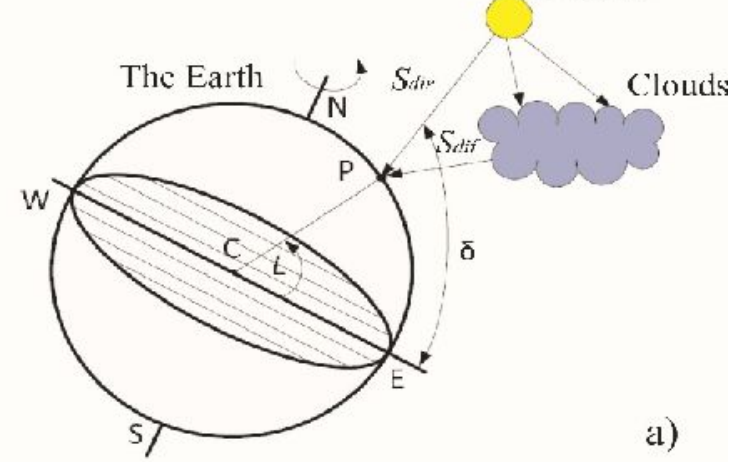

territory for SPP. Selectionof a territorymeans choosing a place with high insolation of surface. First, it depends on the geographic place of the area's location, the area's relief, the angle of inclination, and the direction of slope.

In order to use solar energy, we should know the visible path of the Sun during the day, although in most cases there is no necessity to determine the exact position of the Sun at a certain time. (Fig. 3). This, in turn, reduces the number of calculations required to determine the Sun's path, and therefore we can neglect the location's longitude. (Häberlin, 2012).

Fig. 3(a) shows the Earth rotating around its axis that passes through the points of the North Celestial Pole (N) and the South Celestial Pole (S). This axis is perpendicular to the equatorial plane of the Earth passing through the points $\mathrm{W}$ and E, which respectively indicate western and eastern directions. The centre of the Earth is marked with point C.

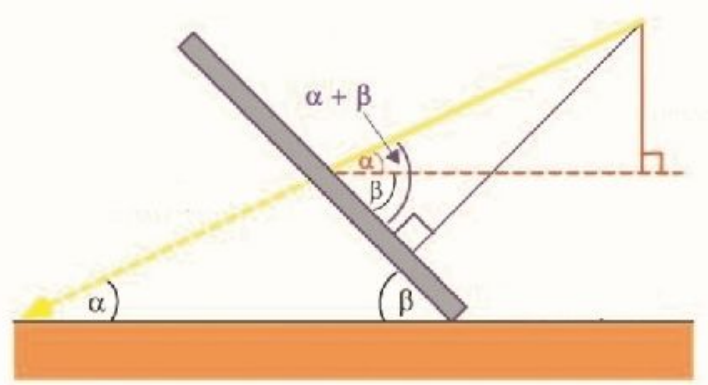

b)

Fig. 3. Solar radiance (a), which is falling on the inclined surface (b) 
Point $\mathrm{P}$ on the Earth's surface indicates the location of the reflect-prevention panel and it is characterized by the geographical latitude $\mathrm{L}$, which equals $48^{\circ}$ in Ivano-Frankivsk region. The angle between the direction to the Sun and the equatorial plane is called the inclination $\delta$, which is a measure of seasonal changes.

The position of the Sun in the sky is not constant during the year because of inclination of the Earth's rotation axis with respect to the normal line to the plane of its motion around the Sun. We mark the Earth's inclination in relation to the Sun as $\delta$. Thus, in the northern hemisphere, at the latitude $\varphi=48^{\circ}$, at the highest point of the solstice, the Sun position can be described by value $\alpha$ :

$$
\omega=90^{\circ}-\delta
$$

In order to determine the optimal value of the angle of solar module (Fig. 3b) for an area with latitude $\varphi=48^{\circ}$, at which the solar module must be inclined to the horizon, initially we have to determine the average number of angles (the inclination of the Sun) for all months of the years.

$$
\delta=\Sigma \eta / n
$$

where, $\eta$ - the average value of the angles in months, $n$ - number of months.

In this case

$\delta=(21,01+30,38+41,32+53,04+61,24+64,1$

$1+60,82+52,52+41,31+30,02+20,94+17,51) / 12$ $=41^{\circ}$.

Now, according to formula 1 , we can calculate the optimal angle of solar modules' inclination.

$$
\omega=90^{\circ}-41^{\circ}=49^{\circ} \text {. }
$$

Geo-information analyses of insolation level. Thegeo-morphological characteristic of IvanoFrankivsk region is represented by the topographic maps, slope exposures, and the angles of inclination. They are built in Vertical Mapper MapInfo software environment.

Zonal insolation map (Fig. 1) is presented with morphological peculiarities of the studied region and it needs to be specified in detail.

It is obvious, that the value of the solar insolation cannot be the same throughout the region as it undergoes the influence of other natural and technological factors. Such peculiarities are described in detail and analysed above.

Understanding the features peculiar to the movement of the Sun in the sky permits us to assert that the insolation value is uneven during the day and at a certain point, which is determined by the coordinate, in particular.

The Sun's parameters, which are determinative at calculation of the solar insolation, should be reduced to the morphometric characteristics of the territory.

The angle of inclination above the horizon the Sun's inclination, the slope exposure - the azimuth of the Sun shall be reduced to the single coefficients, which permit us to specify information as to the insolation level of the chosen region.

Thus, on the basis of the presented morphometric maps (Fig.4), we have created a number of special inquiries to determine the solar insolation level within the insolation zones (Fig. 1).

While creating inquiries, which include recalculation of the insolation level ( ) according to the reduced level ( $\left.{ }_{n p}.\right)$, we have determined the effective time for obtaining solar energy per each month: January 9:00 - 16:00; February 8:00 17:00; March 7:00 - 18:00; April 6:00 - 19:00; May 5:00 - 19:00; June 5:00 - 20:00; July 5:00 - 20:00; August 6:00 - 19:00; September 7:00 - 18:00; October 7:00 - 17:00; November 8:00 - 16:00; December 9:00 - 16:00.

In accordance with the content of formula 1, that the value of angle of inclination above the horizon $(\alpha)$ and the inclination of the Sun $(\delta)$ cannot exceed $90^{\circ}$ and the slope exposure $(\varepsilon)$ as well as the azimuth of the Sun equal to $360^{\circ}$, the following formulae are offered:

$$
=90^{\circ}-(\alpha+\delta), \quad \quad \quad \quad=360^{\circ}-(\varepsilon+) .
$$

Then, ${ }_{n p}=(/ / 8)^{*}$.

The inquiries have been created under the principle of selecting the point, which contains information about the insolation level, the angle of inclination and the slope exposure relating to Sun's movement during the day (the year). The cartographic material was relatively tied to previously formed information, pursuant to the statistical analysis data (Spearmen's rank-correlation). Recalculation of the insolation value was based on the counting of the reduced insolation coefficient using special data of the point in accordance with the built relief model. More than 600 thousand points were analysed for Ivano-Frankivsk region in total.

Generating of insolation maps. The zonal map is presented on Fig. 5. The map is built by method of triangulation (central part of IvanoFrankivsk region) and it represents the character of insolation in accordance with the grouped months. 

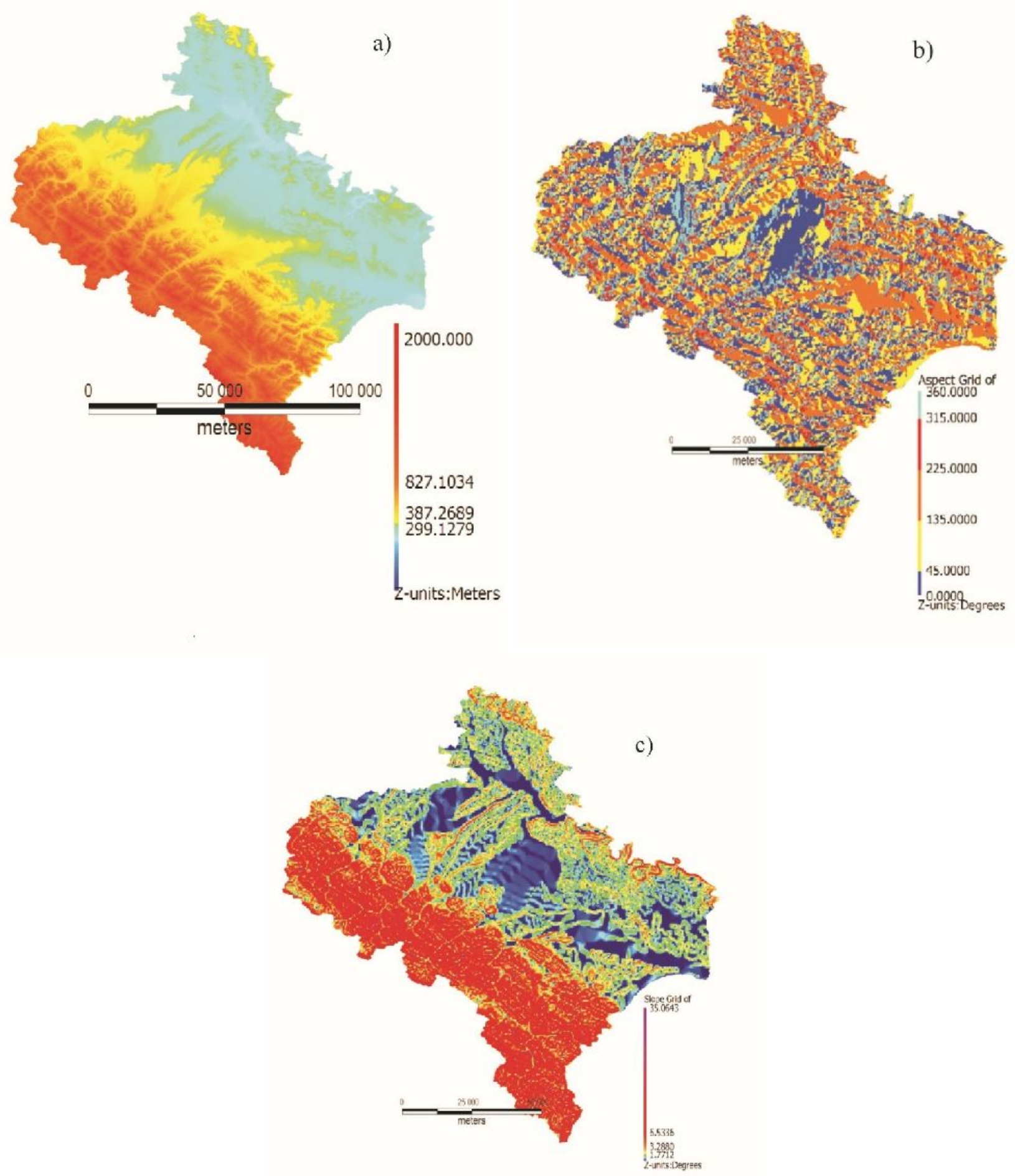

Fig. 4. Morphometric maps: ) heights, b) exposures, c) angles

As it seen from the figure, the level of insolation fluctuates considerably during the year. It is only natural that the values of insolation level should visually offer morphological characteristic of the territory. In this case, the maximum and minimum insolation values, which are fluctuating within the range of the daily zonal maximum $(0-$ $1425 \mathrm{kWh} / \mathrm{m}^{2}$, Fig.1), present a change in the possibly generated solar energy.

Practical importance is also within the same limits but they always exceed zero and are less than
$1425 \mathrm{kWh} / \mathrm{m}^{2}$. This is presented on the maps (Fig. 5).

This indicates that the values of slope exposure mainly and the angle of inclination above the horizon to a lesser degree are important factor characteristics for determination of the level of insolation for any territory. The daily (visible) movement of the Sun characterizes just a degree of the absorbing capacity of the solar-cell panels, but the optimal an-gle of their location is not taken into consideration at that time. 


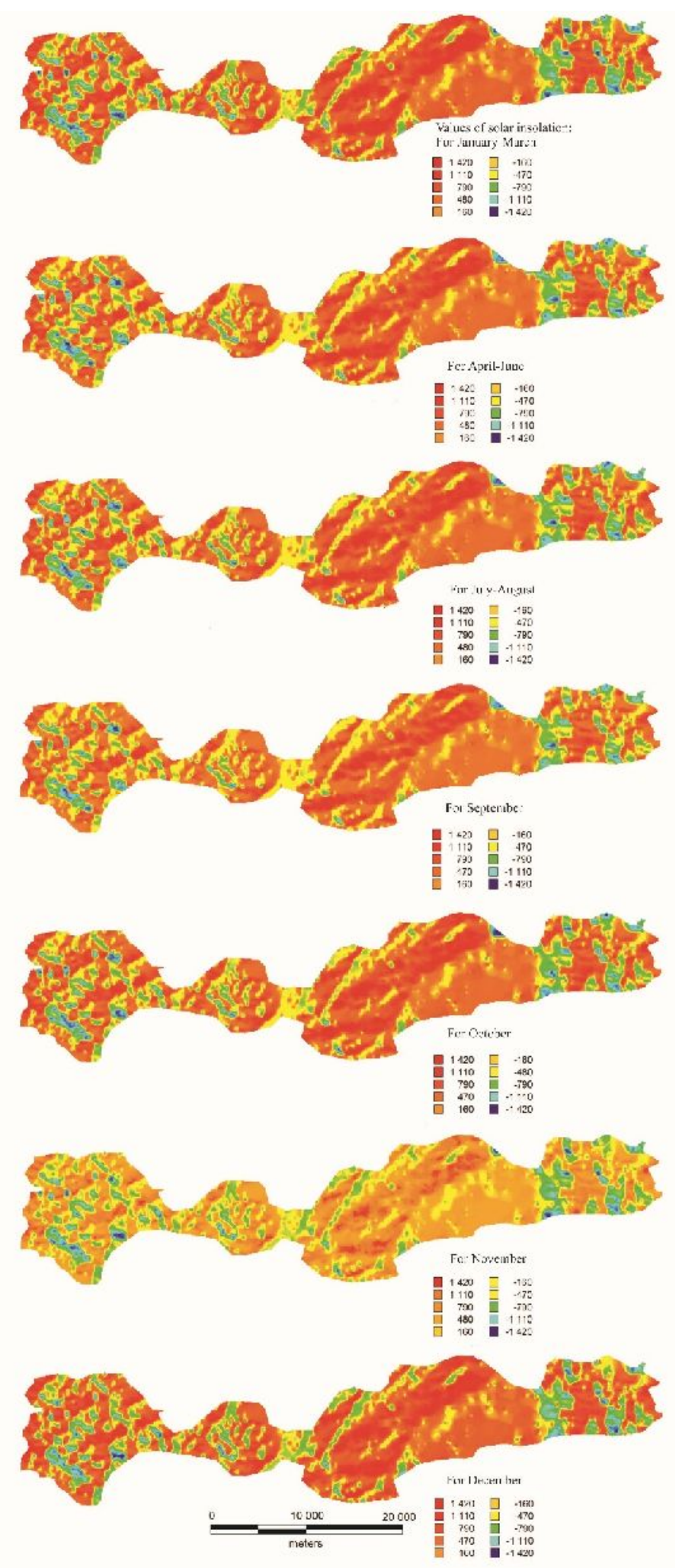

Fig. 5. Zonal maps of insolation

Conclusions and perspectives of further development of research in this direction. The cloud coefficient for each month has been calculated according to the data of reduced insolation and insolation on cloudless days. The built thematic maps of the reduced insolation for Ivano-Frankivsk region were reduced to maps of relief, exposure, and the angle of inclination in order to distribute them for the certain groups of months.

As a result, the maps with the level of insolation for the grouped months with the reduced values were built. The maps show in which way the insolation changes over the year for different conditional regions. Such maps give prerequisites for 
further factor analysis as to the feasibility of using and building of solar power stations in any selected territory.

Perspectives for further development of research are improvement of the quality of calculation of the reduced insolation level by means of increasing the number of re-counted points within the insolation zone and taking into account the new factors.

\section{References}

Häberlin H., 2012. Photovoltaics: System Design and Practice / Heinrich Häberlin. 732.John Twidell, Tony Weir. Taylor \& Francis Ltd, 2015. Renewable Energy Resources. ROUTLEDGE: London, United Kingdom, 816.

Kasiyanchuk, D., Kuzmenko, E., Chepurna, T. and Chepurnyi, I., 2016. Rozrakhunok ekolohoheolohichnoyi otsinky ryzykiv zsuvnoyi nebezpeky[Calculation of that environmental and geological landslide risk estimate]. Eastern European Journal of Enterprise Technologies, 1(10), 18 25. DOI: $10.15587 / 1729-4061.2016 .59687$ (in Ukrainian).

Kasiyanchuk, D.V.,Chepurna, T.B., Chepurnyi, I.V. and Hurtska N.V., 2015. Metodolohiya kil'kisnoyi prohnoznoyi otsinky ryzykiv ekzohennykh heolohichnykh protsesiv z vykorystannyam HIStekhnolohiy [Methodology of quantitative forecasting risk assessments of exogenous geological processes using GIS technology]. International Conference Geoinformatics: Theoretical and Applied Aspects. DOI: 10.3997/22144609.201412408 (in Ukrainian).

Kazakov G.V, 2013. Morfolohichna rol insolyatsiyi v arkhitekturi mistobudivnoho seredovyshcha [Morphological role of insolation in the architecture of city-planning environment]. Bulletin of the National University "Lviv Polytechnic". Series: Architecture. № 757, 398 - 402 (in Ukrainian).

Suri ., CebecauerT., HuldT., DunlopE. D., 2001-2008. Map of solar radiation in Europe: Ukraine. Materi-als of JRC European commission. - PVGIS: European communities, 27.
NASA Surface meteorology and Solar Energy Choices, 2018. Atmospheric Science Data Centre. Retrieved from https://eosweb.larc.nasa.gov/cgibin/sse/grid.cgi?email=\&step $=1 \&$ lat $=\& l o n=\&$ sub mit=Submit.

Omar Ellabbanab, Haitham, Abu-Rubb, Frede Blaabjergc Reviews, 2014. Renewable energy resources: Current status, future prospects and their enabling technology. Renewable and Sustainable Energy. Volume 39, November, 748 - 764

DotsenkoS., TymchukS., ShendrykS., ShulymaO., 2016. Rozrakhunok potuznosti insolyatsyi dlya prognozuvannya vyrobnytsnva electrychnoyi energiyi fotoelektrychnymy panelyamy [Calculation of capacity insolation for forecasting the production of electrical energy by photovoltaic panels]. Bulletin of Kharkov National Technical University of Agriculture P. Vasilenko. № 176, 8 - 11 (in Ukrainian).

Sukhodolya . ., 2016. Enerhetychna stratehiia Ukrainy na period do 2035. [Power strategy of Ukraine for the period through to 2035]. Retrieved from http://niss.gov. ua/public/File/2014.../Energy\%20Strategy\%2020 35.pdf.

Tiapkin, O.K., Pihulevskyi, P.H.,Dovbnich, M.M., 2017. Taking into account of influence of earth crust faults in solving geological and geoecological tasks by geophysical methods. Naukovyi Visnyk Natsionalnoho Hirnychoho Universytetu, 6, 15 22 (in English).

Tymkiv M M , Kasiyanchuk D.V., 2017. Analiz vidnovlyuval'nykh dzherel enerhiyi na terytoriyi IvanoFrankivs'koyi oblasti z vykorystannyam heoinformatsiynykh system [Analysis of renewable energy sources in Ivano-Frankivsk region using geoinformation systems]. Ecological safety and balanced resource use - № 2 (16), 153-159 (in Ukrainian).

GelichyV., OmelychukO., ShapovalS., VengrinI., 2015. Enerhetychnyy potentsial sonyachnoyi radiatsiyina terytoriyi Ukrayiny. [The energy potential of solar radiation in Ukraine]. Bulletin of the National University "Lviv Polytechnic". Series: Theory and practice of construction: a collection of scientific works, № 823, 117 - 121 (in Ukrainian). 